\title{
Changes in pro-environmental behaviour and its determinants during long-term period in a transition country as Lithuania
}

\author{
Audronè Minelgaitè $\dot{1}^{1}$ Genovaitè Liobikiené $\dot{1}^{1}$
}

Received: 31 October 2020 / Accepted: 11 March 2021 / Published online: 22 March 2021

(c) The Author(s), under exclusive licence to Springer Nature B.V. 2021

\begin{abstract}
The changes in pro-environmental behaviour, whether people become more environmentally friendly or not, have been analysed very scarcely. Therefore, the aim of this paper was to analyse the changes in pro-environmental behaviour and its determinants in Lithuania as a transition European Union country comparing years 2011 and 2020. Applying Chi-Square and test statistics, the results showed a significant increase in performance of pro-environmental behaviour in 2020. Waste sorting and purchase of environmentally friendly goods increased the most, meanwhile water and energy saving behaviour increased the least. Applying the value-belief-norm theory and leaner regression analysis, we analysed whether the same determinants influenced pro-environmental behaviour in 2011 and 2020. The results revealed that the impact of determinants differed. In 2020, the main factor of pro-environmental behaviour was the perception of environmental problems but not self-transcendence values dimension. Furthermore, self-enhancement values and awareness of behavioural consequences negatively influenced pro-environmental behaviour in 2020. Analysing the changes in these factors, an insignificant difference was observed in self-enhancement values. The changes in other factors were significant, particularly the changes in the level of environmental responsibility was the biggest. Therefore, implementation of environmental education and information programmes and various environmentally friendly public initiatives positively contributed to the enhancement of environmental awareness and pro-environmental behaviour.
\end{abstract}

Keywords Pro-environmental behaviour $\cdot$ Environmental responsibility $\cdot$ Environmental problems $\cdot$ Values $\cdot$ Environmental education

Genovaitė Liobikienè

genovaite.liobikiene@vdu.lt

1 Department of Environmental Sciences, Vytautas Magnus University, Donelaičio str. 28, 44404 Kaunas, Lithuania 


\section{Introduction}

Authors analysing environmental impact stated that unsustainable consumption or environmentally unfriendly behaviour are related to environmental issues (Schröder et al., 2019; Paddock, 2016; Brizga et al., 2017; Vergragt et al., 2016). The pro-environmental behaviour and sustainable consumption is related to the promotion of sustainable production as converting organic waste into clean fuels (Fahmy et al. 1982, 2017, 2020). Therefore, according to literature reviews, a large number of researchers applying various theories have examined the determinants of pro-environmental behaviour and how to promote it (Farrow et al., 2017; Lange \& Dewitte, 2019; Li et al., 2019; Yuriev et al., 2020). Considering that researchers have very extensively analysed pro-environmental behaviour and provided tools how to enhance this behaviour, the changes in these factors were scarcely examined. Therefore, it is of primary importance to analyse the changes in pro-environmental behaviour and to reveal whether people have become more environmentally friendly or not.

In this study we analysed the changes in pro-environmental behaviour comparing years 2011 and 2020. This study encompassed a stabilized economic period, without any disturbances of economic crisis or pandemics. In this paper, the value-belief-norm and goal framing theories were applied. In recent years, Van Riper et al. (2019), Liu et al. (2018), Hiratsuka et al. (2018), Liobikienè and Poškus (2019) and Zhang et al. (2020) also used value-belief-norm and Polhill and Gotts (2017) applied goal framing theory. Bronfman et al. (2015), Janmaimool and Khajohnmanee (2020) and Parajuly et al. (2020) stated that the value-belief-norm theory is arguably the most usable of moral theories in exploring the factors of pro-environmental behaviour. In our previous research we analysed the impact of (i) self-enhancement, (ii) self-transcendence values as well as (iii) environmental problem perception, (iv) awareness of behavioural consequences and (v) assumption of responsibility on pro-environmental behaviour in Lithuania in 2011 (Liobikiene and Juknys, 2016). The task of this paper was to prove whether the same determinants still influenced proenvironmental behaviour in 2020. It was important to analyse whether the determinants have changed during the analysed period. If the answer were positive, then policymakers should use the same tools to promote pro-environmental behaviour, if negative-policymakers should choose different ways to enhance pro-environmental behaviour. Furthermore, it was important to evaluate whether the level of determinants has changed during the analysed period and what could have contributed to these changes. The aim of this paper was to analyse the changes in pro-environmental behaviour and its determinants during a long-term ( 9 years) period. To the best of our knowledge, none of previous authors have analysed the changes in pro-environmental behaviour and its determinants. This study provides new insights for policymakers and evaluates the effectiveness of implementing tools.

\section{Literature review}

\subsection{Changes in pro-environmental behaviour and its determinants}

In the reviewed literature, authors have analysed short-term changes in pro-environmental behaviour over one year period or behaviour before and after implementing education programme (Chankrajang \& Muttarak, 2017; Leeuw et al., 2015; Meyer, 2016). Lauper 
et al. (2015) explored eco-driving behaviour over four months. Rosenthal (2018) assessed the procedural information impact on recycling over one month. Other authors, as Huber et al. (2018), analysed 5 years of longitudinal US data and evaluated changes in household recycling. Otto et al. (2019) examined changes in environmental attitude and behaviour of children. Xiao and Buhrmann (2019) investigated how environmental attitudes and beliefs supported the self-reported environmental actions and environmental policies in 1997 and 2012 in US.

Authors analysing behavioural spillover effects have taken time series data and analysed the impact of the past behaviour. A positive spillover reveals that one type of proenvironmental behaviour engages to perform additional pro-environmental behaviour. A negative spillover reduces the likelihood of additional pro-environmental behaviour (Geng et al., 2019; Maki et al., 2019; Nilsson et al., 2016). However, to analyse the changes in pro-environmental behaviour and to reveal taking into account long-term period whether people have become more environmentally friendly or not is necessary as well.

Furthermore, considering the main determinants of pro-environmental behaviour, Franzen and Vogl (2013) explored the changes in environmental concern. A large number of authors have investigated changes in climate change concern, scepticism, and perception (Bergquist \& Warshaw, 2019; Capstick et al., 2015; Prati et al., 2018; Whitmarsh \& Capstick, 2018) and its determinants. However, to the best of our knowledge, none of researchers have analysed the changes in determinants of pro-environmental behaviour as values, perception of environmental issues, awareness and environmental responsibility.

\subsection{Value-belief-norm theory analysing the determinants of pro-environmental behaviour}

The theory of value-belief-norm suggested by Stern (2000) includes the factors related to internal factors. According to this theory, values influence environmental attitudes, awareness of behavioural consequences and assumption of responsibility and contribute to pro-environmental behaviour. Considering value impact on pro-environmental behaviour, authors used two-dimensional structure: self-enhancement and self-transcendence values (Mayekar \& Sankaranaravanan, 2019; Jakob et al., 2018; Punzo et al., 2019; Xu et al., 2018). These values are different and do not overlap (Alcock et al., 2017). Selftranscendence value is related to collective interest concern when people empathize for the welfare of the other people (Chan, 2019), while self-enhancement value encompasses egoistic values seeking self-benefits and concerning individual interest (Liobikiene et al., 2020; Chan, 2019). Authors have usually found that only people with self-transcendence values are more inclined to perform pro-environmental behaviour (Liobikiene and Juknys, 2016; Jakob et al., 2018; Ling \& Xu, 2020; Thomas et al., 2016). Chan (2019) also stated that values related to collective wealth contribute to environmentally friendly behaviour, while self-enhancement values negatively influence this behaviour (Liobikiene and Juknys, 2016; Jacob et al., 2018). However, when different type of pro-environmental behaviour is considered, like a behaviour related to status image as purchase of green products, selfenhancement values positively influence this behaviour (Liobikiene and Juknys, 2016; Liobikiene 2020). Ling and Xu (2020) stated that individuals with greater self-enhancement values are more motivated to behave environmentally friendly, which is beneficial for individuals.

Considering perception of environmental problems, a large number of authors mainly focused on perception (or concern) of climate change impact on pro-environmental 
behaviour. Authors have found that climate change concern (or perceived threat) is an important factor in actions (intentions) related to climate change mitigation (Masud et al., 2016; Lacroix and Gifford., 2018; Yu et al., 2019). On the other hand, Yilmaz and Can. (2019) revealed that concern had an insignificant effect on environmental behaviour. Kuthe et al. (2019) also showed that concern about climate change is not always related to willingness to act climate friendly among teenagers. However, in this paper as in previous our research (Liobikiene and Juknys, 2016), we expected perception of environmental problems to have a positive impact on pro-environmental behaviour.

In the literature, usually the impact of awareness of behavioural consequences on personal norms is analysed (Stern, 2000; Van. Riper \& Kyle, 2014; Fang et al., 2019; Wang et al., 2019). However, authors analysing the direct impact of awareness of behavioural consequences on pro-environmental behaviour have found different results. Liobikiene and Poskus (2019) revealed that awareness of behavioural consequences significantly and positively influenced private but not public behaviour, while in previous our research (Liobikiene et al., 2016), awareness of behavioural consequences insignificantly effected proenvironmental behaviour.

According to value-belief-norm theory, environmental responsibility directly influences pro-environmental behaviour (Stern, 2000). A large number of authors have found that environmental responsibility significantly influenced pro-environmental behaviour (Zareie and Navimpour, 2016; Zhu et al., 2019; Fang et al., 2019; Liobikiene and Poskus, 2019). Liobikiene et al. (2020) and Sarkis (2017) revealed an insignificant responsibility impact on conservation behaviour, while environmental responsibility significantly influenced princely behaviour. In previous our analysis (Liobikiene and Juknys, 2016) we found that assumption of responsibility significantly and positively determined pro-environmental behaviour. Applying value-belief-norm theory in this paper, we analysed whether the determinants which influenced pro-environmental behaviour in 2011 also determined behaviour in 2020, and how these effects have changed during the analysed period.

\section{Methods}

\subsection{Characteristics of two survey samples}

In order to assess the changes in pro-environmental behaviour and its factors, the data of two surveys conducted in 2011 and in 2020 were used. The first part of the survey was conducted from 8 to 17 April 2011 when 1011 Lithuanian residents were interviewed. The second part of the same survey was conducted in the period from 10 January to 1 February 2020 and 1027 Lithuanian citizens were interviewed. These periods of time encompassed stabilized economic period, without any disturbances of economic crisis or pandemics. In 2020, the survey was conducted before the coronavirus pandemic. Thus, this analysis revealed how implemented environmental information and education programmes contribute to changes in pro-environmental behaviour and its determinants.

Both surveys were carried out by market analysis and research group 'RAIT' ['RAIT' has confirmed that surveys meet the relevant quality requirements of ESOMAR (European Public Opinion and Market Research Associations)]. The same target group of the Lithuanian population by age was used in both periods. Representative probabilistic sampling was used to select 15-74 years respondents, estimating on proportional distribution of the population by age and sex. As we see from Table 1 where the demographic characteristics 
Table 1 Demographic characteristics of surveys in 2011 and 2020

\begin{tabular}{lll}
\hline & Percentage (number) 2011 & $\begin{array}{l}\text { Percentage } \\
\text { (number) } \\
2020\end{array}$ \\
\hline $\begin{array}{l}\text { Gender } \\
\text { Male }\end{array}$ & \\
Female & $47(477)$ & $48(491)$ \\
Age & $53(534)$ & $52(536)$ \\
$15-24$ & & \\
$25-34$ & $16(162)$ & $12(121)$ \\
$35-44$ & $12(117)$ & $20(200)$ \\
$45-54$ & $17(177)$ & $15(157)$ \\
$55-64$ & $19(191)$ & $18(188)$ \\
$65-74$ & $17(173)$ & $21(215)$ \\
\hline
\end{tabular}

are presented, these characteristics are rather similar. The statistical error of the data is $3 \%$ and the confidence interval is $95 \%$.

\subsection{Questionnaire scales}

In this paper we used the same scales as in our previous research (Liobikiene and Juknys, 2016). Answers to the questions were ranged based on the Likert four-point scale from 1 (completely unimportant/strongly disagree) to 4 (very important/strongly agree). Analysing the value impact, we applied two-dimensional structure: self-enhancement and selftranscendence value dimensions. The scale of 'Perception of environmental problems' encompasses all environmental problems, including local and global problems. 'Pro-environmental behaviour' scale measured conservation, green purchase and recycling behaviours, referring to Zhao et al. (2014); Rodríguez-Barreiro et al. (2013). The internal reliability of the all scale items in both surveys was calculated using Cronbach's alpha. As we can see in Table 2, the values of Cronbach's alpha are rather similar in both years. The values of Cronbach's alpha $0.5-0.75$ and $<0.75$ reveal a generally acceptable, respectively, moderate and highly reliable scale (Hinston et al., 2004). Therefore, the scales are stable and well-constructed.

\subsection{The statistical analysis of the proposed model}

In order to assess the changes in pro-environmental behaviour and its determinants the Chi-Square statistic was applied. This statistic is applied to assess the differences between dichotomous and ordinal variables. Analysing the changes in pro-environmental behaviour, perception of environmental problems, self-enhancement and self-transcendence values means, $t$ test was applied. The $p$ value $<0.05$ was considered to be significant.

To reveal whether the same determinants influenced pro-environmental behaviour in both years 2011 and 2020, the leaner regression analysis was applied. We analysed the impact of (i) self-enhancement and (ii) self-transcendence values, (iii) perception of environmental problems, (iv) awareness of behavioural consequences and (v) environmental responsibility on pro-environmental behaviour. In previous research (Liobikiene and 
Table 2 Questionnaire items used in the surveys and reliability analysis

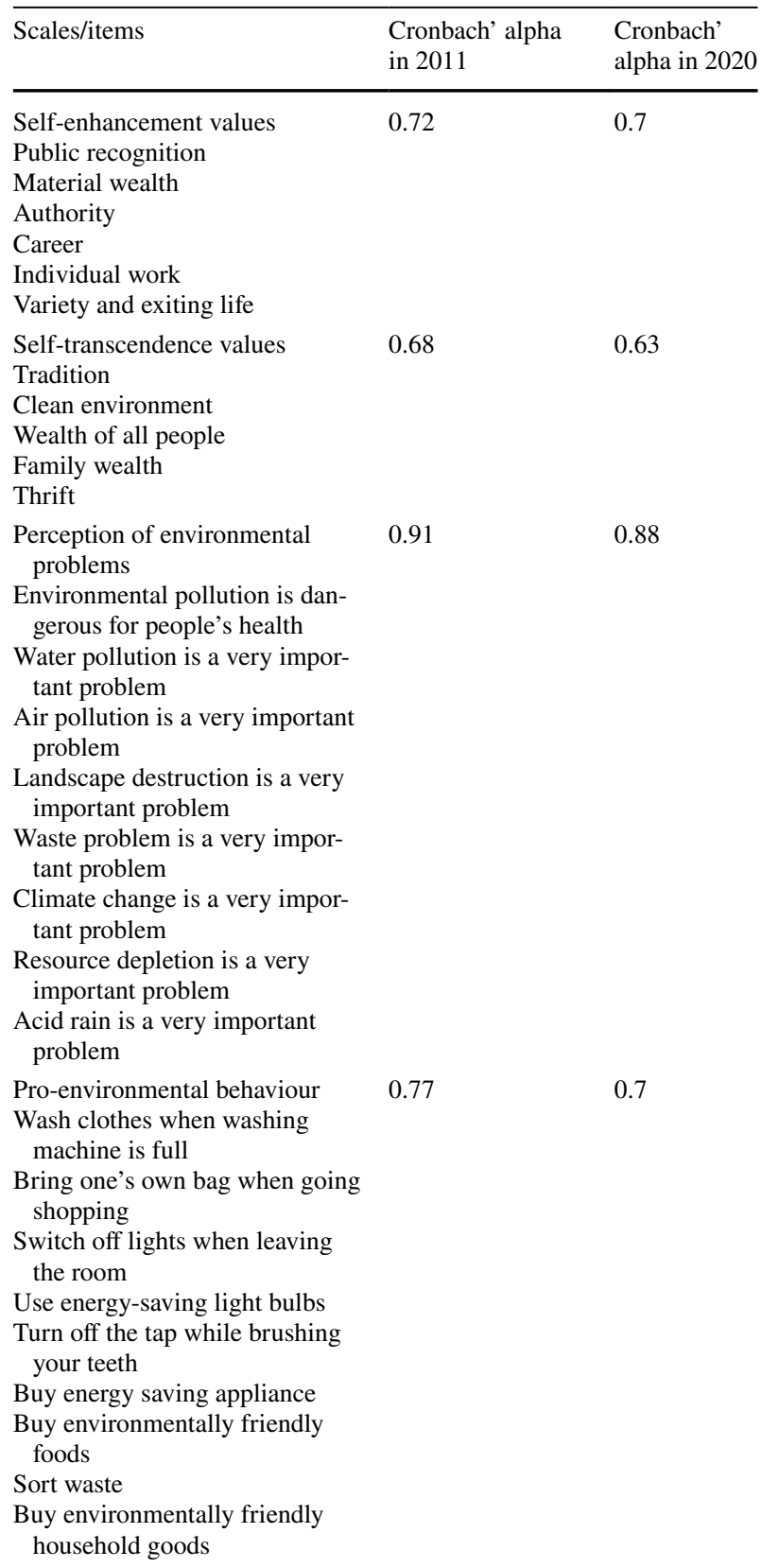

Juknys, 2016), the demographic characteristics were included. In this paper, we excluded these variables, because we only focused on variables which can be influenced by environmental education and other programmes. Both models were estimated using ordinary least square regression and revealed which factor influenced pro-environmental behaviour directly and the most. All preconditions of regression analyses were checked. The 
normality and collinearity diagnostics revealed that models are suitable. Standardized beta coefficients and $t$ values showed which factors and how influenced pro-environmental behaviour.

\section{Results and discussion}

\subsection{Changes in pro-environmental behaviour}

Comparing the performance of pro-environmental behaviour in 2011 and 2020 in Fig. 1, we see that Lithuanian people in 2020 became more environmentally friendly and they were more frequently inclined to perform all types of pro-environmental behaviour. The difference between pro-environmental behaviour in 2011 and 2020 was statistically significant. The biggest change was observed in waste sorting behaviour. In 2011, respondents remarked that from all pro-environmental behaviours they sorted waste the least. Meanwhile, in 2020, a large share of respondents stated that they sort waste often or always. The main reason for citizens to sort waste more could be that during the analysed period the waste recycling has been highly developed. In Lithuania, there are well developed recycling and composting facilities in most areas. Even people in rural area have containers and can sort waste more conveniently. These tools of sorting promotion were the most preferred in Lithuania (Minelgaite and Liobikiene, 2019). Furthermore, people were more informed about waste problems. During analysed period, vast educational programmes of why and how to sort waste were implemented in kindergartens and schools. Thus, the waste policy in Lithuania has been successfully developed and the increased performance of sorting behaviour has been evaluated very positively.

In 2020, a high increase in the purchase of environmental-friendly household goods, energy saving appliances and usage of energy-saving light bulbs was observed. The latter behaviour respondents performed most frequently in 2020. The increased performance of these behaviours could be related to implementation of stricter standards on energy

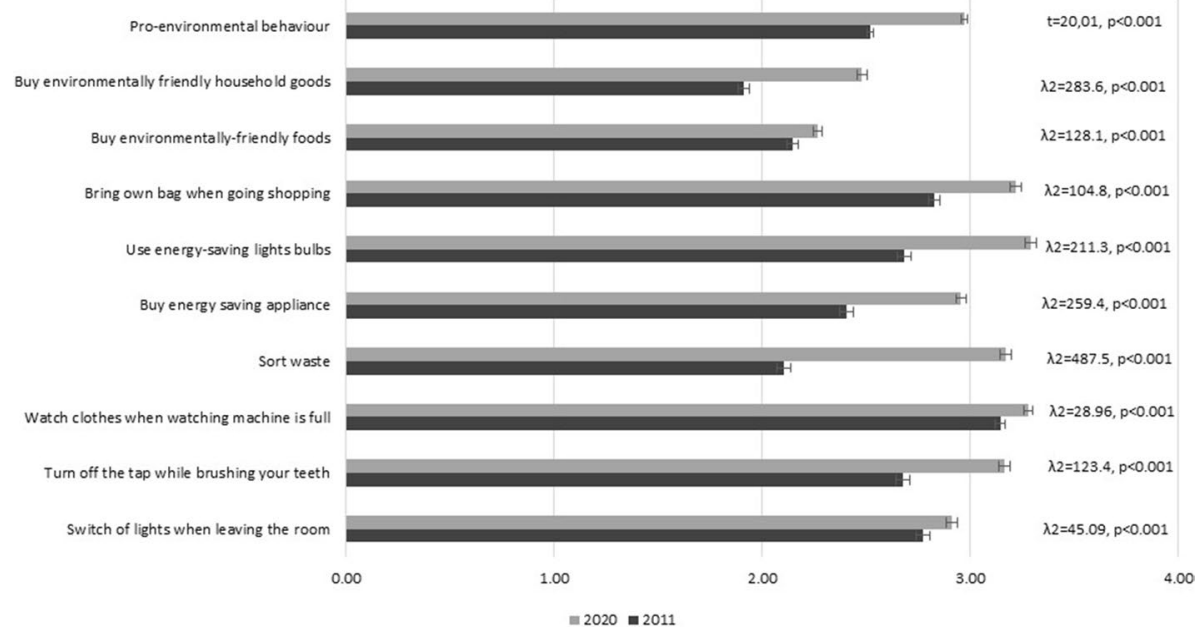

Fig. 1 The tendencies of pro-environmental behaviour in 2011 and 2020 
appliances and bulbs. To buy not energy-saving bulbs in Lithuania is almost impossible. Energy-saving appliances are also popular in Lithuania, and producers are mostly focused on the production of environmentally friendly appliances. During recent years, the chemical household goods were most criticized and people seeking to live healthier changed their habits and began to purchase more environmentally friendly and health-friendly goods. However, despite the high increase in the purchase of these products, this type of behaviour remains the most problematic, and people are not very inclined to buy environmentally friendly household goods. The increase in purchase of environmentally friendly food comparing with household goods was lower (Fig. 1). The growth of environmentally friendly food purchase could be related to the fact that due to successful EU Cohesion policy people became richer and had higher incomes. Furthermore, the supply of green food increased as well as eco-farming increased in Lithuania. However, respondents were the least inclined to buy environmentally friendly food in 2020 .

The conservation behaviour performances as 'turn off the tap while brushing teeth', 'bring one's own bag to the shop', 'switch off lights' and 'wash clothes when washing machine is full', changed the least comparing 2011 and 2020, particularly the latter behaviour. These behaviours in 2011 were performed the most frequently. In 2020, the same tendencies were observed, particularly concerning the conservation behaviour related to water saving (Fig. 1). These types of behaviour are attributed to habit and are not very easy to change (Liobikiene et al., 2020). However, it is positively evaluated that people are inclined to save water even when they become richer. Lithuanian citizens also rather often noticed that they bring their own bag when going shopping. This tendency is related to the fact that markets and shops are willing to reduce the purchase of plastic bags and instead offer to buy durable linen (cotton) bags, which are rather expensive. Thus, people are more motivated to bring their own (durable and fashionable) bag to the shop. The change in the performance of 'switch off lights when leaving the room' was one of the smallest as people were not inclined to perform this behaviour frequently in 2020. This result shows a rebound effect, when people using energy-saving bulbs are not inclined to save energy switching off the light. On the other hand, it could be related to the fact that switching off the light when leaving a room for the short time is ineffective and producers suggested doing it only if we leave the room for a long time.

\subsection{Factors of pro-environmental behaviour in 2011 and 2020}

To evaluate whether the factors of pro-environmental behaviour changed or not, we applied the regression analysis and analysed the same factors in both year 2011 and 2020. We analysed the impact of values, perception of environmental problems, awareness of behavioural consequences and environmental responsibility on environmentally friendly behaviour. From results presented in Table 3 we see that according to models' summary in 2011 its explanatory variables account for $13.6 \%$ of the variance, while in 2020 for $22.5 \%$ of the variance. Therefore, the model in 2020 was more suitable.

In 2011, we found that self-transcendence value orientation influenced environmentally friendly behaviour the most. Perception of environmental problems was the second determinant which contributed to pro-environmental behaviour. The impact of environmental responsibility was the least. Thus, self-enhancement and awareness of behavioural consequences negatively but insignificantly influenced pro-environmental behaviour. In 2020, the impact of determinants was different. The perception of environmental problems became the most important factor contributing to pro-environmental behaviour. 
Table 3 Regression results of pro-environmental behaviour in 2011 and 2020

\begin{tabular}{|c|c|c|c|c|c|c|}
\hline & \multicolumn{3}{|c|}{ Standardized coefficients 2011} & \multicolumn{3}{|c|}{ Standardized coefficients 2020} \\
\hline & Beta & $t$ & Sig & Beta & $t$ & Sig \\
\hline (Constant) & & 5.859 & $<0.001$ & & 12.321 & $<0.001$ \\
\hline Self-enhancement & -0.017 & -0.528 & 0.597 & -0.093 & -3.110 & 0.002 \\
\hline Self-transcendence & 0.223 & 6.584 & $<0.001$ & 0.249 & 7.342 & $<0.001$ \\
\hline Perception of environmental problems & 0.183 & 5.312 & $<0.001$ & 0.254 & 6.957 & $<0.001$ \\
\hline Awareness of behavioural consequences & -0.031 & -0.941 & 0.347 & -0.119 & -3.960 & $<0.001$ \\
\hline Environmental responsibility & 0.107 & 3.212 & 0.001 & 0.117 & 3.347 & 0.001 \\
\hline$R^{2}$ & 0.136 & & & 0.225 & & \\
\hline
\end{tabular}

Self-transcendence value dimension was the second factor which influenced pro-environmental behaviour. Environmental responsibility in 2011 determined the pro-environmental behaviour the least. However, the effect of environmental responsibility strengthened in 2020. Self-enhancement values and awareness of behaviour consequences in 2020 negatively and significantly influenced pro-environmental behaviour. Therefore, despite that in 2011 the impact of these factors was insignificant, in 2020 it was big enough to decrease the performance of pro-environmental behaviour (Table 3). Considering the environmentally friendly behaviour in general, we confirmed findings of other authors that selfenhancement values negatively influence pro-environmental behaviour (Liobikiene and Juknys, 2016; Jacob et al., 2018; Evans et al., 2013). The awareness of pro-environmental behaviour consequences also negatively influenced pro-environmental behaviour. In our previous study (Liobikiene and Juknys, 2016) we interpreted these results that the gap between awareness of behavioural consequences and behaviour occurred due to the lack of environmental knowledge about real behaviour impact, time, money, etc. However, this study corrected our interpretation. We found that people who declared that their behaviour did not contribute to environmental issues were more inclined to perform pro-environmental behaviour and vice versa, people who declared that their behaviour contributed to environmental impact behaved environmentally unfriendly. To sum up, it revealed that people understand that behaving more environmentally friendly they would reduce their personal environmental impact. The promotion of awareness of behavioural consequences is important because, as Stern (2000), Hansla et al. (2008), De Groot and Steg (2007), Liobikiene and Juknys (2016) and Steg (2014) stated, it is the main prerequisite for the assumption of environmental responsibility.

\subsection{Changes in determinants of pro-environmental behaviour}

The value dimension impact on pro-environmental behaviour is important. However, our study revealed that values are rather constant. Considering self-transcendence values, changes in family wealth and wealth of all people from 2011 to 2020 were insignificant. The biggest change was observed of tradition value and it influenced that self-transcendence values differed in 2011 and 2020 significantly. Therefore, the globalization process reduces the following of traditions. The fast economic growth and consumerism during analysed period also statistically significantly decreased the thrift value. The clean environment in 2020 became more important than in 2011 (Fig. 2(left)). It can be 

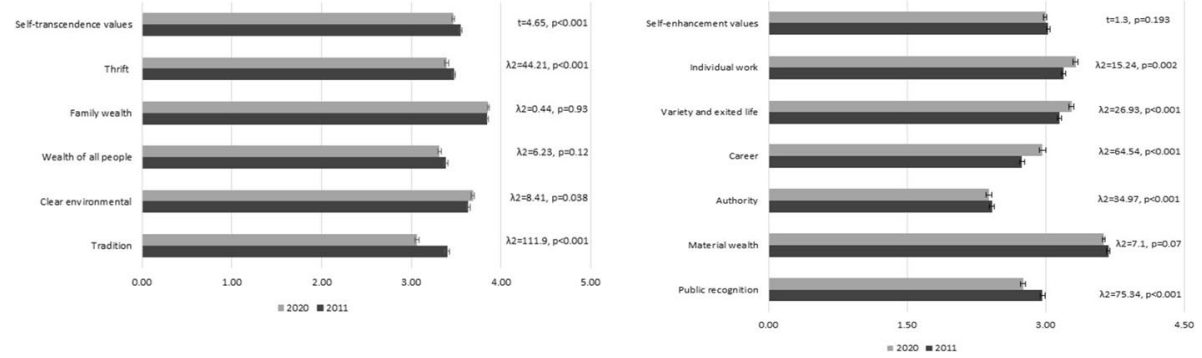

Fig. 2 Tendencies of self-transcendence (left) and self-enhancement (right) values in 2011 and 2020

related that people understand more about the value of clean environment and its influence on people's well-being.

Considering the self-enhancement, all values (except material wealth) of this dimension differed statistically significantly. From 2011 to 2020, the public recognition and authority value became significantly reduced but career, individual work and varied and exciting life increased significantly with the latter dimension increasing the most. It is related to enhanced ability to travel and spend more money on entertainment. Altogether, the changes in self-enhancement values were insignificant (Fig. 2 (right)). Our study confirmed that values are rather constant as was stated by other authors (Brown \& Kasser, 2005; Hansla et al., 2008; Papagiannakis \& Lioukas, 2012; Stern et al., 1995; van der Werff, 2013; Van Riper \& Kyle, 2014).

The perception of environmental problems increased significantly comparing 2011 and 2020. The biggest increase was observed in perception of waste problem and water pollution. The information about waste and increase in landfills was disseminated the most during the analysed period. Furthermore, all environmental education programmes were mainly focused on waste management. The increased importance of water pollution is related to the fact that in the last year several scandals occurred in Lithuania, related to water pollution from big producers as 'Grigeo', when Curonian Lagoon was polluted. An increased pollution of rivers was also observed. All these scandals were uncovered by active public. Therefore, water pollution was the most important problem in 2020 in Lithuania. Other local environmental problems as air pollution, landscape destruction and waste problems, which increased as well, were important problems in Lithuania. Therefore, we confirmed findings of our previous research and other authors that local environmental problems remain more important comparing to regional or global problems (Liobikiene and Juknys 2016; Nistor, 2008, Zsoka et al., 2013).

The importance of climate change increased in Lithuania also rather highly. Despite the increase in information provision about climate change, this problem is evaluated rather low in Lithuania. Out of all analysed environmental problems climate change, acid rain and resource depletion were evaluated as the least important environmental problems (Fig. 3). The low importance of climate change could be related to the occurrence of 'psychological distance' (Broomell et al., 2015) described in detail by Brügger et al. (2015) and McDonald et al. (2015). Climate change is an abstract phenomenon, which is difficult to assess and not always related to personal experience (Weber, 2015; Van der Linden et al., 2015). Therefore, people are not interested in this problem. In 2011, environmental pollution as a danger for people's health was evaluated the highest. However, analysing the differences between 2011 and 2020, this change was the least as compared to other environmental problems (Fig. 3). Therefore, in Lithuania the 


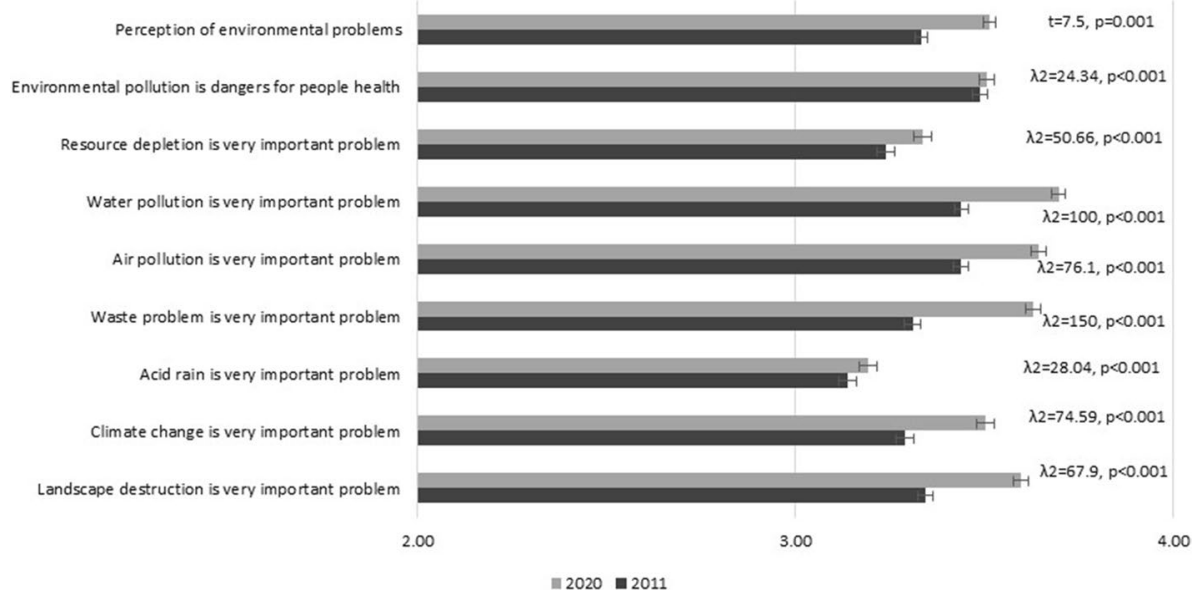

Fig. 3 Changes in importance of environmental problems in 2011 and 2020

environmental quality did not worsen very much and the situation did not become very dangerous for people's health.

In 2011, the awareness of behavioural consequences was the lowest, when only about $14 \%$ of respondents stated that they absolutely agree that their behaviour contributes to environmental issues (Liobikienè and Juknys, 2016). In 2020, a significant increase in awareness of behavioural consequences was revealed (Fig. 4). People got more informed about the consequences of behaviour. In $2020,22 \%$ of respondents stated that they absolutely agree that their behaviour is related to environmental problems.

Analysing the environmental responsibility in 2011, people mostly attributed responsibility of environmental problems solution to industry and government, but not to themselves (Liobikiene and Juknys, 2016). In 2020, the situation remained the same (Fig. 4). Respondents remarked that government and industry are most responsible for solving

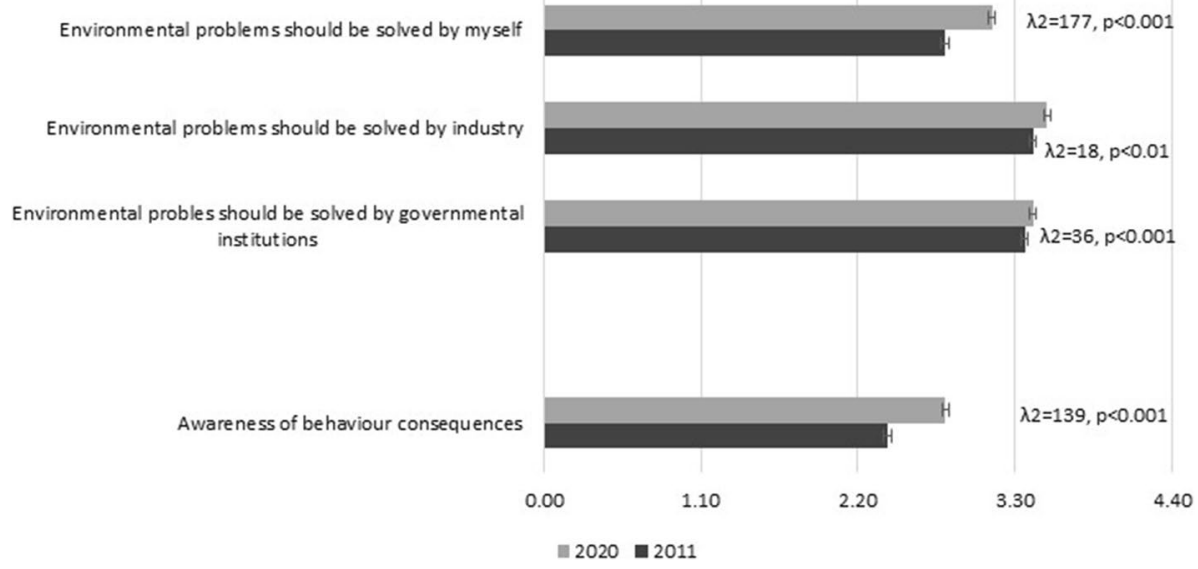

Fig. 4 Changes in awareness of behavioural consequences and attribution of responsibility for solutions to environmental problems 
environmental problems. However, the personal environmental responsibility increased the most and almost achieved the level of responsibility attributed to industry and government. These tendencies are evaluated very positively. The growth of environmental responsibility is required seeking enhancement of pro-environmental behaviour. The increase in environmental responsibility could be related to the fact that citizens noticed the failure of government to solve environmental problems. In the face of scandals, citizens noticed that industry seeks more the profit but not better environmental standards. Furthermore, the emergence of various environmental initiatives as 'A Day without a Car', 'Let's Do It! World' or 'Earth Hour', which became very popular 5-9 years ago, could contribute to an increase in environmental responsibility. Particularly young people are most active and enthusiastically participate in these initiatives (Hayward, 2012; Poškus, 2017, 2018). The movement 'Friday for future' which was initiated by Greta Thunberg two years ago could also have influenced an increase in environmental responsibility in Lithuania.

\section{Policy implications}

Implementing various environmental programmes and initiatives the main target is to increase the environmental awareness and environmentally friendly behaviour of citizens. Analysing the changes in environmentally friendly behaviour, we found that respondents were more inclined to behave in pro-environmentally way in 2020 than in 2011 . Thus, the implemented environmental policy, environmental information and education programmes, successfully promoted pro-environmental behaviour in Lithuania, particularly waste sorting behaviour. However, despite the high increase in purchase of environmentally friendly household goods and foods, these types of behaviour remain the most problematic. Thus, policymakers should promote green food consumption more by facilitating eco-farm certifications, increasing the supply, which can reduce the cost differences of eco and conventional products. Meanwhile, the performance of conservation behaviour increased the least, particularly switching off lights when leaving the room. Therefore, the citizens need concrete information on how to save energy switching off lights in the rooms.

Analysing the determinants of pro-environmental behaviour, the effect of environmental responsibility on pro-environmental behaviour strengthened in 2020. Therefore, the provision of information about environmental problems remains the main tool in order to enhance pro-environmental behaviour. The assumption of environmental responsibility should be enhanced as well. Respondents, who declared that they contribute to environmental impact, should be motivated by getting more knowledge about how to decrease the environmental impact and about benefits of these behaviours. Furthermore, considering that values are rather constant, environmental policymakers can contribute to the promotion of pro-environmental behaviour by highlighting and enhancing the status or benefit of these behaviours.

Considering that people are not interested in global problems, they should be more informed about the climate change, resource depletion and its consequences in particular. The level of environmental responsibility increased the most. Implementation of environmental education and information programmes, various environmentally friendly public initiatives positively contributed to the enhancement of environmental awareness. However, a small share of respondents still do not agree or partially disagree that they should be solving environmental problems. Therefore, environmental programmes should be further extensively implemented. 


\section{Conclusions}

The changes in pro-environmental behaviour, whether people become more environmentally friendly or not, have been analysed very scarcely in literature. The aim of this paper is to analyse the changes in pro-environmental behaviour and its determinants comparing years 2011 and 2020 in Lithuania as a transition country in the European Union. Analysing the changes in environmentally friendly behaviour, we found that respondents were more inclined to behave in pro-environmentally way in 2020 than in 2011, and this difference was significant. The waste sorting and purchase of environmentally friendly goods increasing the most. Meanwhile, the performance of conservation behaviour increased the least. The change in the performance of switching off lights when leaving the room was one of the least and people were not inclined to perform this behaviour frequently in 2020 .

Analysing the main factors of pro-environmental behaviour in 2011 and 2020, we applied the value-belief-norm theory. The results revealed that the impact of analysed determinants differed. In 2020, the main factor of environmentally friendly behaviour was the perception of environmental problems, but not self-transcendence values dimension. The effect of environmental responsibility on pro-environmental behaviour strengthened in 2020. Self-enhancement values and awareness of behavioural consequences negatively influenced pro-environmental behaviour in 2020. Analysing the changes in determinants of pro-environmental behaviour in 2011 and 2020, insignificant differences were observed in self-enhancement values. The changes in self-transcendence values, perception of environmental problems, awareness of behavioural consequences and environmental responsibility were significant. The level of environmental responsibility increased the most.

\section{References}

Alcock, I., White, M. P., Taylor, T., Coldwell, D. F., Gribble, M. O., Evans, K. L., \& Fleming, L. E. (2017). "Green" on the ground but not in the air: Pro-environmental attitudes are related to household behaviours but not discretionary air travel. Global Environmental Change, 42, 136-147. https://doi.org/10. 1016/j.gloenvcha.2016.11.005

Bergquist, P., \& Warshaw, C. (2019). Does global warming increase public concern about climate change? The Journal of Politics, 81(2), 686-691. https://doi.org/10.1086/701766

Brizga, J., Feng, K., \& Hubacek, K. (2017). Household carbon footprints in the Baltic States: A global multiregional input-output analysis from 1995 to 2011. Applied Energy, 189, 780-788. https://doi.org/10. 1016/j.apenergy.2016.01.102

Bronfman, N., Cisternas, P., López-Vázquez, E., Maza, C., \& Oyanedel, J. (2015). Understanding attitudes and pro-environmental behaviors in a chilean community. Sustainability, 7, 1413314152. https://doi. org/10.3390/su71014133

Broomell, S. B., Budescu, D. V., \& Por, H.-H. (2015). Personal experience with climate change predicts intentions to act. Global Environmental Change, 32, 67-73. https://doi.org/10.1016/j.gloenvcha.2015. 03.001

Brown, K. W., \& Kasser, T. (2005). Are psychological and ecological well-being compatible? The role of values, mindfulness, and lifestyle. Social Indicators Research, 74, 349-368. https://doi.org/10.1007/ s11205-004-8207-8

Brügger, A., Dessai, S., Devine-Wright, P., Morton, T. A., \& Pidgeon, N. F. (2015). Psychological responses to the proximity of climate change. Nature Climate Change, 5(12), 1031-1037. https://doi.org/10. $1038 /$ nclimate 2760

Capstick, S., Whitmarsh, L., Poortinga, W., Pidgeon, N., \& Upham, P. (2015). International trends in public perceptions of climate change over the past quarter century. WIREs Climate Change, 6, 35-61. https:// doi.org/10.1002/wcc.321 
Chan, H.-W. (2019). When do values promote pro-environmental behaviors? Multilevel evidence on the self-expression hypothesis. Journal of Environmental Psychology. https://doi.org/10.1016/j.jenvp. 2019.101361

Chankrajang, T., \& Muttarak, R. (2017). Green returns to education: Does schooling contribute to pro-environmental behaviours? Evidence from Thailand. Ecological Economics, 131, 434-448. https://doi.org/ 10.1016/j.ecolecon.2016.09.015

De Leeuw, A., Valois, P., Ajzen, I., \& Schmidt, P. (2015). Using the theory of planned behavior to identify key beliefs underlying pro-environmental behavior in high-school students: Implications for educational interventions. Journal of Environmental Psychology, 42, 128-138. https://doi.org/10.1016/j. jenvp.2015.03.005

Evans, L., Maio, G. R., Corner, A., Hodgetts, C. J., Ahmed, S., \& Hahn, U. (2013). Selfinterest and proenvironmental behaviour. Nature Climate Change, 3(2), 122-125. https://doi.org/10.1038/nclimate16 62

Fahmy, T. Y. A., Fahmy, Y., Mobarak, F., et al. (2020). Biomass pyrolysis: Past, present, and future. Environment, Development and Sustainability, 22, 17-32. https://doi.org/10.1007/s10668-018-0200-5

Fahmy, Y., Fahmy, T. Y. A., Mobarak, F., et al. (2017). Agricultural residues (wastes) for manufacture of paper, board, and miscellaneous products: Background overview and future prospects. International Journal of ChemTech Research, 10, 424-448.

Fahmy, Y., Mobarak, F., \& Schweers, W. (1982). Pyrolysis of agricultural residues. II. Yield and chemical composition of tars and oils produced from cotton stalks, and assessment of lignin structure. Cellulose Chemistry and Technology, 16, 453-459.

Fang, W.-T., Chiang, Y.-T., Ng, E., \& Lo, J.-C. (2019). Using the norm activation model to predict the proenvironmental behaviors of public servants at the central and local governments in Taiwan. Sustainability, 11(13), 3712. https://doi.org/10.3390/su11133712

Farrow, K., Grolleau, G., \& Ibanez, L. (2017). Social norms and pro-environmental behavior: A review of the evidence. Ecological Economics, 140, 1-13. https://doi.org/10.1016/j.ecolecon.2017.04.017

Franzen, A., \& Vogl, D. (2013). Two decades of measuring environmental attitudes: A comparative analysis of 33 countries. Global Environmental Change, 23(5), 1001-1008. https://doi.org/10.1016/j.gloenvcha. 2013.03.009

Geng, L., Chen, Y., Ye, L., Zhou, K., \& Chen, Y. (2019). How to predict future pro-environmental intention? The spillover effect of electricity-saving behavior under environmental and monetary framing. Journal of Cleaner Production, 233, 1029-1037. https://doi.org/10.1016/j.jclepro.2019.06.088

Hansla, A., Gamble, A., Juliusson, A., \& Gärling, T. (2008). The relationships between awareness of consequences, environmental concern, and value orientations. Journal of Environmental Psychology, 28, 1-9. https://doi.org/10.1016/j.jenvp.2007.08.004

Hayward, B. (2012). Children, citizenship and environment. Routledge.

Hinston, P. H., Brownlow, C., McMurray, I., \& Cozens, B. (2004). SPSS explanation. Routledge.

Hiratsuka, J., Perlaviciute, G., \& Steg, L. (2018). Testing VBN theory in Japan: Relationships between values, beliefs, norms, and acceptability and expected effects of a car pricing policy. Transportation Research Part F: Traffic Psychology and Behaviour, 53, 74-83. https://doi.org/10.1016/j.trf.2017.12. 015

Huber, J., Viscusi, W. K., \& Bell, J. (2018). Dynamic relationships between social norms and pro-environmental behavior: Evidence from household recycling. Behavioural Public Policy. https://doi.org/10. 1017/bpp.2017.13

Jacobs, K., Petersen, L., Hörisch, J., \& Battenfeld, D. (2018). Green thinking but thoughtless buying? An empirical extension of the value-attitude-behaviour hierarchy in sustainable clothing. Journal of Cleaner Production, 203, 1155-1169. https://doi.org/10.1016/j.jclepro.2018.07.320

Janmaimool, P., \& Khajohnmanee, S. (2020). Enhancing university students' global citizenship, public mindedness, and moral quotient for promoting sense of environmental responsibility and pro-environmental behaviours. Environment, Development and Sustainability, 22, 957-970. https://doi.org/10. 1007/s10668-018-0228-6

Kuthe, A., Keller, L., Körfgen, A., Stötter, H., Oberrauch, A., \& Höferl, K.-M. (2019). How many young generations are there?-A typology of teenagers' climate change awareness in Germany and Austria. The Journal of Environmental Education, 50(3), 172-182. https://doi.org/10.1080/00958964.2019. 1598927

Lacroix, K., \& Gifford, R. (2018). Psychological barriers to energy conservation behavior: The role of worldviews and climate change risk perception. Environment and Behavior, 50(7), 749-780. https:// doi.org/10.1177/0013916517715296

Lange, F., \& Dewitte, S. (2019). Measuring pro-environmental behavior: Review and recommendations. Journal of Environmental Psychology, 63, 92-100. https://doi.org/10.1016/j.jenvp.2019.04.009 
Lauper, E., Moser, S., Fischer, M., Matthies, E., \& Kaufmann-Hayoz, R. (2015). Psychological predictors of eco-driving: A longitudinal study. Transportation Research Part F: Traffic Psychology and Behaviour, 33, 27-37. https://doi.org/10.1016/j.trf.2015.06.005

Li, D., Zhao, L., Ma, S., Shao, S., \& Zhang, L. (2019). What influences an individual's pro-environmental behavior? A literature review. Resources, Conservation and Recycling, 146, 28-34. https://doi.org/10. 1016/j.resconrec.2019.03.024

Ling, M., \& Xu, L. (2020). Relationships between personal values, micro-contextual factors and residents' pro-environmental behaviors: An explorative study. Resources, Conservation and Recycling, 156, 104697. https://doi.org/10.1016/j.resconrec.2020.104697

Liobikienè, G., \& Juknys, R. (2016). The role of values, environmental risk perception, awareness of consequences, and willingness to assume responsibility for environmentally-friendly behaviour: the Lithuanian case. Journal of Cleaner Production, 112, 3413-3422. https://doi.org/10.1016/j.jclepro.2015.10. 049

Liobikienè, G., Liobikas, J., Brizga, J., \& Juknys, R. (2020). Materialistic values impact on pro-environmental behavior: The case of transition country as Lithuania. Journal of Cleaner Production, 244, 118859. https://doi.org/10.1016/j.jclepro.2019.118859

Liobikienė, G., \& Poškus, M. S. (2019). The importance of environmental knowledge for private and public sphere pro-environmental behavior: Modifying the Value-Belief-Norm theory. Sustainability, 11, 3324. https://doi.org/10.3390/su11123324

Liu, X., Zou, Y., \& Wu, J. (2018). Factors influencing public-sphere pro-environmental behavior among Mongolian college students: A test of Value-Belief-Norm theory. Sustainability, 10(5), 1384. https:// doi.org/10.3390/su10051384

Maki, A., Carrico, A. R., Raimi, K. T., Truelovem, H. B., Araujo, B., \& Yeung, K. L. (2019). Meta-analysis of pro-environmental behaviour spillover. Nature Sustainability, 2, 307-315. https://doi.org/10.1038/ s41893-019-0263-9

Masud, M. M., Al-Amin, A. Q., Junsheng, H., Ahmed, F., Yahaya, S. R., Akhtar, R., \& Banna, H. (2016). Climate change issue and theory of planned behaviour: Relationship by empirical evidence. Journal of Cleaner Production, 113, 613-623. https://doi.org/10.1016/j.jclepro.2015.11.080

Mayekar, M. R. M., \& Sankaranaravanan, K. G. (2019). Values as predictors of consumers' green product purchase behavior. International Journal of Green Economics. https://doi.org/10.1504/IJGE.2019. 101443

McDonald, R. I., Chai, H. Y., \& Newell, B. R. (2015). Personal experience and the "psychological distance" of climate change: An integrative review. Journal of Environmental Psychology, 44, 109-118. https:// doi.org/10.1016/j.jenvp.2015.10.003

Meyer, A. (2016). Heterogeneity in the preferences and pro-environmental behavior of college students: The effects of years on campus, demographics, and external factors. Journal of Cleaner Production, 112, 3451-3463. https://doi.org/10.1016/j.jclepro.2015.10.133

Minelgaitè, A., \& Liobikienè, G. (2019). The problem of not waste sorting behaviour, comparison of waste sorters and non-sorters in European Union: Cross-cultural analysis. Science of the Total Environment, 672, 174-182. https://doi.org/10.1016/j.scitotenv.2019.03.342

Nilsson, A., Bergquist, M., \& Schultz, W. P. (2016). Spillover effects in environmental behaviors, across time and context: a review and research agenda. Environmental Education Research, 23(4), 573-589. https://doi.org/10.1080/13504622.2016.1250148

Nistor, L. (2008). Rootless and clustered environmentally significant consumption. In: Sustainable Consumption 2008 Conference. Corvinus University of Budapest, Hungary, 101-118. October 8, 2008: Academic conference proceedings.

Otto, S., Evans, G. W., Moon, M. J., \& Kaiser, F. G. (2019). The development of children's environmental attitude and behavior. Global Environmental Change, 58, 101947. https://doi.org/10.1016/j.gloenvcha. 2019.101947

Paddock, J. (2016). Household consumption and environmental change: Rethinking the policy problem through narratives of food practice. Journal of Consumer Culture, 17(1), 122-139. https://doi.org/10. $1177 / 1469540515586869$

Papagiannakis, G., \& Lioukas, S. (2012). Values, attitudes and perceptions of managers as predictors of corporate environmental responsiveness. Journal of Environmental Management, 100, 41-51. https://doi. org/10.1016/j.jenvman.2012.01.023

Parajuly, K., Fitzpatrick, C., Muldoon, O., \& Kuehr, R. (2020). Behavioral change for the circular economy: A review with focus on electronic waste management in the EU. Resources, Conservation and Recycling: $X$. https://doi.org/10.1016/j.rcrx.2020.100035

Polhill, G., \& Gotts, N. (2017). How precise are the specifications of a psychological theory? Comparing implementations of Lindenberg and Steg's goal-framing theory of everyday pro-environmental 
behaviour. In W. Jager, R. Verbrugge, A. Flache, G. de Roo, L. Hoogduin, \& C. Hemelrijk (Eds.), Advances in social simulation 2015. Advances in intelligent systems and computing. Springer. https:// doi.org/10.1007/978-3-319-47253-9_31

Poškus, M. S. (2017). Normative influence of pro-environmental intentions in adolescents with different personality types. Current Psychology. https://doi.org/10.1007/s12144-017-9759-5

Poškus, M. S. (2018). Investigating pro-environmental behaviors of Lithuanian university students. Current Psychology, 37, 225-233. https://doi.org/10.1007/s12144-016-9506-3

Prati, G., Pietrantoni, L., \& Albanesi, C. (2018). Human values and beliefs and concern about climate change: A Bayesian longitudinal analysis. Quality and Quantity, 52, 1613-1625. https://doi.org/10. 1007/s11135-017-0538-z

Punzo, G. (2019). Assessing the role of perceived values and felt responsibility on pro-environmental behaviours: A comparison across four EU countries. Environmental Science and Policy, 101, 311-322. https://doi.org/10.1016/j.envsci.2019.09.006

Rodríguez-Barreiro, L. M., Fernandez-Manzanal, M., Serra, L. M., Carrasquer, J., Murillo, M. B., Morales, M. J., Calvo, J. M., \& del Valle, J. (2013). Approach to a causal model between attitudes and environmental behaviour. A graduate case study. Journal of Cleaner Production, 48, 116-125. https://doi.org/ 10.1016/j.jclepro.2012.09.029

Rosenthal, S. (2018). Procedural information and behavioral control: Longitudinal Analysis of the intentionbehavior gap in the context of recycling. Recycling, 3, 5. https://doi.org/10.3390/recycling3010005

Sarkis, M. A., Jr. (2017). A comparative study of theoretical behavior change models predicting empirical evidence for residential energy conservation behaviours. Journal of Cleaner Production, 141, 526537. https://doi.org/10.1016/j.jclepro.2016.09.067

Schröder, P., Vergragt, P., Halina, B., Dendler, L., Gorenflo, N., Matus, K., \& Wennersten, R. (2019). Advancing sustainable consumption and production in cities-A transdisciplinary research and stakeholder engagement framework to address consumption-based emissions and impacts. Journal of Cleaner Production, 213, 114-125. https://doi.org/10.1016/j.jclepro.2018.12.050

Steg, L., Bolderdijk, J. W., Keizer, K., \& Perlaviciute, G. (2014). An integrated framework for encouraging pro-environmental behaviour: The role of values, situational factors and goals. Journal of Environmental Psychology, 38, 104-115. https://doi.org/10.1016/j.jenvp.2014.01.002

Stern, P. (2000). Toward a coherent theory of environmentally significant behaviour. Journal of Social Issues, 56(3), 407-424.

Stern, P. C., Dietz, T., Kalof, L., \& Guagnano, G. A. (1995). Values, beliefs, and pro-environmental action: Attitude formation toward emergent attitude objects. Journal of applied social psychology, 25, 16111636. https://doi.org/10.1111/j.1559-1816.1995.tb02636.x

Thomas, G. O., Poortinga, W., \& Sautkina, E. (2016). The Welsh single-use carrier bag charge and behavioural spillover. Journal of Environmental Psychology, 47, 126-135. https://doi.org/10.1016/j.jenvp. 2016.05.008

Van der Linden, S., Maibach, E., \& Leiserowitz, A. (2015). Improving public engagement with climate change. Perspectives on Psychological Science, 10(6), 758-763. https://doi.org/10.1177/1745691615 598516

van der Werff, E., Steg, L., \& Keizer, K. (2013). The value of environmental self-identity: The relationship between biospheric values, environmental self-identity and environmental preferences, intentions and behaviour. Journal of Environmental Psychology, 34, 55-63. https://doi.org/10.1016/j.jenvp.2012.12. 006

Van Riper, C. J., \& Kyle, G. T. (2014). Understanding the internal processes of behavioral engagement in a national park: A latent variable path analysis of the value-belief-norm theory. Journal of Environmental Psychology, 38, 288-297. https://doi.org/10.1016/j.jenvp.2014.03.002

van Riper, C., Winkler-Schor, S., Foelske, L., Keller, R., Braito, M., Raymind, C., Eriksson, M., Golebie, E., \& Johnson, D. (2019). Integrating multi-level values and pro-environmental behavior in a U.S. protected area. Sustainability Science, 14, 1395-1408. https://doi.org/10.1007/s11625-019-00677-w

Vergragt, P. J., Dendler, L., de Jong, M., \& Matus, K. (2016). Transitions to sustainable consumption and production in cities. Journal of Cleaner Production, 134, 1-12. https://doi.org/10.1016/j.jclepro.2016. 05.050

Wang, S., Wang, J., Zhao, S., \& Yang, S. (2019). Information publicity and resident's waste separation behavior: An empirical study based on the norm activation model. Waste Management, 87, $33-42$. https://doi.org/10.1016/j.wasman.2019.01.038

Weber, E. U. (2015). What shapes perceptions of climate change? New research since 2010. Wiley Interdisciplinary Reviews: Climate Change, 7(1), 125-134. https://doi.org/10.1002/wcc.377

Whitmarsh, L., \& Capstick, S. (2018). Perceptions of climate change. Psychology and Climate Change. https://doi.org/10.1016/b978-0-12-813130-5.00002-3 
Xiao, C., \& Buhrmann, J. (2019). Ideas to action: Environmental beliefs, behaviors, and support for environmental policies. Journal of Environmental Studies and Sciences, 9, 196-205. https://doi.org/10.1007/ s13412-019-00541-4

Xu, L., Zhang, X., \& Ling, M. (2018). Pro-environmental spillover under environmental appeals and monetary incentives: Evidence from an intervention study on household waste separation. Journal of Environmental Psychology, 60, 27-33. https://doi.org/10.1016/j.jenvp.2018.10.003

Yilmaz, V., \& Can, Y. (2019). Impact of knowledge, concern and awareness about global warming and global climatic change on environmental behavior. Environment, Development and Sustainability. https://doi.org/10.1007/s10668-019-00475-5

Yu, T.-K., Chang, Y.-J., Chang, I.-C., \& Yu, T.-Y. (2019). A pro-environmental behavior model for investigating the roles of social norm, risk perception, and place attachment on adaptation strategies of climate change. Environmental Science and Pollution Research, 26(24), 25178-25189. https://doi.org/10. 1007/s11356-019-05806-7

Yuriev, A., Dahmen, M., Paillé, P., Boiral, O., \& Guillaumie, L. (2020). Pro-environmental behaviors through the lens of the theory of planned behavior: A scoping review. Resources, Conservation and Recycling, 155, 104660. https://doi.org/10.1016/j.resconrec.2019.104660

Zareie, B., \& Navimipour, N. J. (2016). The impact of electronic environmental knowledge on the environmental behaviors of people. Computers in Human Behavior, 59, 1-8. https://doi.org/10.1016/j.chb. 2016.01.025

Zhang, L., Ruiz-Menjivar, J., Luo, B., Liang, Z., \& Swisher, M. E. (2020). Predicting climate change mitigation and adaptation behaviors in agricultural production: A comparison of the theory of planned behavior and the Value-Belief-Norm Theory. Journal of Environmental Psychology, 68, 101408. https://doi.org/10.1016/j.jenvp.2020.101408

Zhao, H.-H., Gao, Q., Wu, Y.-P., Wang, Y., \& Zhu, X. D. (2014). What affects green consumer behaviour in China? A case study from Qingdao. Journal of Cleaner Production, 63, 343-351. https://doi.org/10. 1016/j.jclepro.2013.05.021

Zhu, H., Wong, N., \& Huang, M. (2019). Does relationship matter? How social distance influences perceptions of responsibility on anthropomorphized environmental objects and conservation intentions. Journal of Business Research, 95, 62-70. https://doi.org/10.1016/j.jbusres.2018.10.008

Zsóka, A., Szerényi, Z. M., Széchy, A., \& Kocsis, T. (2013). Greening due to environmental education? Environmental knowledge, attitudes, consumer behavior and everyday pro-environmental activities of Hungarian high school and university students. Journal of Cleaner Production, 48, 126-138. https:// doi.org/10.1016/j.jclepro.2012.11.030

Publisher's Note Springer Nature remains neutral with regard to jurisdictional claims in published maps and institutional affiliations. 